\title{
SOIL ORGANIC MATTER RECOVERY IN SEMIARID GRASSLANDS: IMPLICATIONS FOR THE CONSERVATION RESERVE PROGRAM ${ }^{1}$
}

\author{
INGRID C. BURKE \\ Department of Forest Sciences and Natural Resource Ecology Laboratory, Colorado State University, \\ Fort Collins, Colorado 80523 USA \\ William K. Lauenroth and Debra P. Coffin \\ Department of Rangeland Ecosystem Science and Natural Resource Ecology Laboratory, Colorado State University, \\ Fort Collins, Colorado 80523 USA
}

\begin{abstract}
Although the effects of cultivation on soil organic matter and nutrient supply capacity are well understood, relatively little work has been done on the long-term recovery of soils from cultivation. We sampled soils from 12 locations within the Pawnee National Grasslands of northeastern Colorado, each having native fields and fields that were historically cultivated but abandoned $50 \mathrm{yr}$ ago. We also sampled fields that had been cultivated for at least $50 \mathrm{yr}$ at 5 of these locations.

Our results demonstrated that soil organic matter, silt content, microbial biomass, potentially mineralizable $\mathrm{N}$, and potentially respirable $\mathrm{C}$ were significantly lower on cultivated fields than on native fields. Both cultivated and abandoned fields also had significantly lower soil organic matter and silt contents than native fields. Abandoned fields, however, were not significantly different from native fields with respect to microbial biomass, potentially mineralizable $\mathrm{N}$, or respirable $\mathrm{C}$. In addition, we found that the characteristic small-scale heterogeneity of the shortgrass steppe associated with individuals of the dominant plant, Bouteloua gracilis, had recovered on abandoned fields. Soil beneath plant canopies had an average of $200 \mathrm{~g} / \mathrm{m}^{2}$ more C than between-plant locations.

We suggest that $50 \mathrm{yr}$ is an adequate time for recovery of active soil organic matter and nutrient availability, but recovery of total soil organic matter pools is a much slower process. Plant population dynamics may play an important role in the recovery of shortgrass steppe ecosystems from disturbance, such that establishment of perennial grasses determines the rate of organic matter recovery.
\end{abstract}

Key words: agroecosystem; Conservation Reserve Program (CRP); cultivation; microbial biomass; nitrogen mineralization; shortgrass steppe; soil organic matter recovery.

\section{INTRODUCTION}

Long-term cultivation practices in the central grassland region of the United States have led to significant and widespread losses in soil organic matter (Haas et al. 1957, Aguilar et al. 1988, Burke et al. 1989). These losses are generally attributed to cultivation and crop effects that both increase outputs from soil organic matter and decrease plant residue inputs (Tiessen et al. 1982, Tivy 1987). Tillage increases erosion and decomposition through physical mixing, degradation of soil aggregates, and enhanced contact of litter and interaggregate soil organic matter with decomposing organisms (Elliott 1986, Doran and Werner 1990). Plant residue inputs into cropped soils are significantly lower than in native ecosystems because of residue removal (Doran 1980a), and probably also because annual crop plants have lower belowground production than native perennial grasses. Several decades of continuous cultivation have led to losses in surface soil organic matter (0-20 cm depth) of between 20 and 40\% (Haas et al.

${ }^{1}$ Manuscript received 30 March 1994; revised 20 September 1994; accepted 26 September 1994.
1957, Tiessen et al. 1982, Burke et al. 1989). These losses occur from both active and more recalcitrant pools of soil organic matter (Parton et al. 1983). Decreases in active soil organic matter (sensu Parton et al. 1988) over several decades result in lowered $\mathrm{N}$ mineralization rates. Such historical losses of soil organic matter have represented a significant transfer of $\mathrm{C}$ to the atmosphere (Burke et al. 1991), as well as significant losses in productive potential of a region (Bauer and Black 1994).

A large amount of research has been conducted on the effects of cultivation on soil organic matter and nutrient availability, and a number of recent studies have focused on the short-term (several years) recovery dynamics of reduced- or no-tillage cropping systems. These studies have documented increases in plant residue on the soil surface, increases in soil microbial biomass, and decreases in $\mathrm{N}$ availability due to microbial immobilization following cessation of tillage (Doran 1980a, b. Powlson 1980, Doran and Power 1983, House et al. 1984, Rice and Smith 1984). However, few data are available on the long-term (several decades) dynamics of soil organic matter in ecosystems 
that are recovering from cultivation, in either reducedtillage systems or perennial grasslands.

While much work has concentrated on the quantitative differences in soil organic matter between cropped soils and those under perennial grasslands, very little information is available about the differences in the spatial distribution of soil organic matter between croplands and grasslands. In cropped systems, tillage continually mixes the top $20-30 \mathrm{~cm}$ of the soil , thereby reducing spatial variation created by the presence of individual plants. By contrast, in perennial grasslands individual plants may remain in the same location for many years, thereby having important small-scale effects on the distribution of both $\mathrm{C}$ and $\mathrm{N}$ (Lauenroth et al., in press, Vinton and Burke 1995). Hook et al. (1991), working in the shortgrass steppe, reported significantly higher root $\mathrm{C}$ and $\mathrm{N}$, total and mineralizable soil $\mathrm{N}$, total and respirable soil $\mathrm{C}, \mathrm{C}: \mathrm{N}$ ratio, fraction of organic $\mathrm{C}$ respired, and ratio of respiration to $\mathrm{N}$ mineralized under vs. between individual plants of the dominant species, Bouteloua gracilis (H.B.K.) Lag. ex Griffiths (blue grama) (nomenclature follows Great Plains Flora Association 1986). Therefore, at least in the shortgrass region, small-scale spatial pattern in soil $\mathrm{C}$ and $\mathrm{N}$ appears to be a characteristic feature of native grasslands and an important difference between native grasslands and agroecosystems.

Recently, the Conservation Reserve Program (CRP) (Skold 1989) was enacted in the United States to provide economic incentives for farmers to turn cultivated land back into perennial grassland. The CRP was intended to reduce agricultural over-production and encourage soil conservation. Widespread adoption of this program may be very significant for soil C storage, soil fertility, and ecosystem recovery, but little is known about such possible recovery. The purpose of this study was to examine the recovery of soil organic matter and $\mathrm{N}$ availability on a collection of old fields in the Pawnee National Grasslands in northeastern Colorado. These fields were abandoned during the 1930s and at the time of sampling had undergone at least $53 \mathrm{yr}$ of secondary succession. Our objective was to address two questions about ecosystem recovery. First, can abandoned fields recover total soil organic matter, active soil matter, and $\mathrm{N}$ availability after $53 \mathrm{yr}$ ? Second, is the characteristic small-scale pattern in soil organic matter associated with individual $B$. gracilis plants reestablished in 53 yr?

\section{Methods}

Study sites

We sampled 12 sites in the Pawnee National Grasslands (PNG) and the Central Plains Experimental Range (CPER) in northeastern Colorado during the summer of 1990 (D. P. Coffin, W. K. Lauenroth, and I. C. Burke, unpublished manuscript). The PNG, covering 78100 ha, receives between 320 and $400 \mathrm{~mm}$ of precipitation annually; mean annual temperature ranges from $15.5^{\circ}$ to $16.5^{\circ} \mathrm{C}$. The CPER lies at the western edge of the PNG. Much of the PNG was cultivated prior to 1940 , when the U.S. Government procured this area and released that portion of PNG that had been farmed back into perennial grassland. Currently, the PNG and CPER are managed as rangeland under moderate grazing. Soils of the region are derived from alluvial and eolian material, and are highly variable with respect to order and subgroup depending upon topographic location. Sites within this study were confined to soils of a sandy loam or sandy clay loam texture.

Using aerial photographs, we identified 12 sites within the PNG and across temperature and precipitation gradients at which we could identify native and abandoned fields adjacent to one another (D. P. Coffin, W. K. Lauenroth, and I. C. Burke, unpublished manuscript). At each site, abandoned fields were recognized as being recently cultivated in photos from 1937, and as grassland in photos from every decade since. Native fields were identified as adjacent fields directly to the west; these fields were not identified as cultivated in any of the aerial photographs. At 5 of the sites, we were able to identify fields under continuous cultivation from 1937 to the present. Cultivated fields were not directly adjacent to the abandoned or native fields in several sites, but were located within $0.25 \mathrm{~km}$, and were on the same landscape positions and soil type according to Soil Conservation Service soil series maps (U.S. Department of Agriculture 1982).

\section{Field sampling}

Boundaries for the native, abandoned, and cultivated fields were field-checked against aerial photographs. Soil sampling was done in concert with extensive plant community sampling (D. P. Coffin, W. K. Lauenroth, and I. C. Burke, unpublished manuscript). We located two transects, $50 \mathrm{~m}$ apart from one another, that crossed the native-abandoned field boundary, and extended 90$\mathrm{m}$ into each field. Two 90-m transects were also located across cultivated fields for sampling.

Each transect was divided into 30 -m segments. Within each segment, we randomly located a sample site at which we took four $5.0 \mathrm{~cm}$ diameter cores to a depth of $10 \mathrm{~cm}$, two directly underneath the nearest $B$. gracilis plants, and two in the adjacent, bare interspaces between plants. We stratified our sampling in this fashion because (1) B. gracilis is the dominant perennial plant of the shortgrass steppe, (2) bare ground covers $50-60 \%$ of the surface, (3) previous data suggest that the most significant variation in the system occurs between and under individual perennial plants (Hook et al. 1991, Vinton and Burke 1995), and (4) recovery dynamics were likely to be different under and between individual perennial plants. All of the native and abandoned fields were dominated by perennial plants (D. P. Coffin, W. K. Lauenroth, and I. C. Burke, unpublished manuscript). Although there are slight differences 
among different perennial plant species in their soil nutrient accumulation patterns, those patterns are small compared to plant-interplant patterns (Vinton and Burke 1995), and our goal was to characterize systemlevel responses to cultivation and abandonment. We sampled at shallow depths because it is at these depths that we were most likely to capture recovery dynamics, given the organic matter distributions of these systems (Yonker et al. 1988). In separate work, we have characterized the soil organic matter losses associated with these fields below the plowline (Ihori et al. 1995). Our analysis suggests that there is no reason to believe that surface mixing would influence our comparison of abandoned and cultivated fields.

Each soil core was divided into two depths (0-5 and $5-10 \mathrm{~cm}$ ), and the two samples that represented each depth/microsite combination were composited. Cultivated fields were sampled in the fallow phase and were not stratified by plant-interspace microsite since plants were not present, and small-scale variability induced by plants is mixed upon cultivation.

We chose 3 of the 12 sites for determination of $\mathrm{N}$ and $\mathrm{C}$ mineralization and microbial biomass. These sites spanned the precipitation gradient, from $\approx 330$ to $360 \mathrm{~mm}$ annual precipitation. Soils were collected from these sites in the same fashion as all sites, but were refrigerated and transported back to the laboratory for immediate processing. Samples from all other sites were air-dried and stored for future chemical and physical analyses.

\section{Laboratory analysis}

Fresh samples from the three sites were processed immediately. Each sample was sieved to remove plant fragments and material $>2 \mathrm{~mm}$ in diameter. Each sample was mixed and subsampled for three separate analyses: inorganic $\mathrm{N}$, incubations for potential net $\mathrm{N}$ and $\mathrm{C}$ mineralization, and microbial biomass $\mathrm{C}$ and $\mathrm{N}$. Tengram subsamples were used for $\mathrm{NO}_{3}{ }^{-}$and $\mathrm{NH}_{4}{ }^{+}$determination; these samples were extracted in $50 \mathrm{~mL}$ of $2 \mathrm{~mol} / \mathrm{L} \mathrm{KCl}$. The extracts were filtered and analyzed on an autoanalyzer (EPA 1979). Twenty-five-gram subsamples were placed in a small beaker inside a Mason jar $(0.9 \mathrm{~L}, 1$ quart) with $20 \mathrm{~mL}$ of distilled water to keep the atmosphere saturated, and $5 \mathrm{~mL}$ of $2 \mathrm{~mol} / \mathrm{L}$ $\mathrm{NaOH}$ in a small vial to serve as a $\mathrm{CO}_{2}$ trap (Schimel 1986). Samples were incubated at $25^{\circ} \mathrm{C}$ for $10 \mathrm{~d}$. At the end of the incubation, soils were extracted in 125 $\mathrm{mL}$ of $2 \mathrm{~mol} / \mathrm{L} \mathrm{KCl}$ and analyzed for $\mathrm{NO}_{3}{ }^{-}$and $\mathrm{NH}_{4}{ }^{+}$ as described above. The base trap was titrated with acid (Snyder and Trofymow 1984) to determine the amount of $\mathrm{CO}_{2}$ that had been released during the incubation (potential net $\mathrm{C}$ mineralization). Potential net $\mathrm{N}$ mineralization was calculated as the difference between final and initial inorganic $\mathrm{N}$ content of the soil.

Microbial biomass $\mathrm{C}$ and $\mathrm{N}$ were estimated using the fumigation-incubation procedure developed by Jenkinson and Powlson (1976) and modified by Voroney and Paul (1984). This procedure was considered adequate for comparative purposes among our treatments. The remainder of soil samples from the three sites were air-dried and analyzed for chemical and physical properties in the same way as samples from the other nine sites.

Air-dried soils were passed through a 2-mm sieve and subsampled for soil texture, total $\mathrm{N}$, and total $\mathrm{C}$. A 50-g subsample was used for soil texture using the hydrometer method (Day 1965). Subsamples were then ground and analyzed for total $\mathrm{C}$ and $\mathrm{N}$, using automated combustion analysis.

\section{Statistical analysis}

We tested for the effects of treatment (native, abandoned, and cultivated), depth, and microsite (between and under plants) using a nested analysis of variance (Box et al. 1978) with depth nested within microsite, and microsite nested within treatment. Sites were treated as blocks, with 3 blocks for the variables potential $\mathrm{C}$ and $\mathrm{N}$ mineralization and microbial biomass, and 12 blocks for soil texture, total $\mathrm{N}$, and total $\mathrm{C}$. The latter design (12 blocks) was unbalanced, as only 5 of the blocks contained a cultivated treatment.

Data were also weighted by plant cover, using vegetation data for each site from D. P. Coffin, W. K. Lauenroth, and I. C. Burke (unpublished manuscript) to produce an average estimate over each field (i.e., the microsite and depth stratifications were removed). We assumed for this analysis that the soils collected from under B. gracilis were representative of soils under all plants (Vinton and Burke 1995); all of the fields were dominated by perennial plants at this stage of recovery (D. P. Coffin, W. K. Lauenroth, and I. C. Burke, unpublished manuscript). We multiplied under-plant data in grams per square metre by the proportional cover of all plants, added that to the data from between plants (bare ground) multiplied by the proportion of bare ground, and summed for both depths. These weighted data were analyzed with an analysis of variance testing only for the effect of treatment.

A posteriori range tests were conducted using a Scheffé procedure (SAS Institute 1988). We performed the analyses using SAS statistical software (SAS Institute 1988), with significance levels for all tests 0.05 .

\section{RESULTS}

Total soil $\mathrm{C}$ in the top $10 \mathrm{~cm}$ varied from 2200 to $<1000 \mathrm{~g} / \mathrm{m}^{2}$ across sites and land-use treatments, with no apparent trend with respect to precipitation or temperature. Total $\mathrm{C}$ and $\mathrm{N}$ were significantly different among the three land-use treatments, being highest on native fields and lowest on cultivated fields, for both depths (0-5 and 5-10 cm) (Fig. 1). Both $\mathrm{C}$ and $\mathrm{N}$ were significantly higher under than between plants on both native and abandoned fields, and were significantly higher in surface than subsurface soils. Because tillage results in mixing of the top $20-30 \mathrm{~cm}$ of the soil, there 

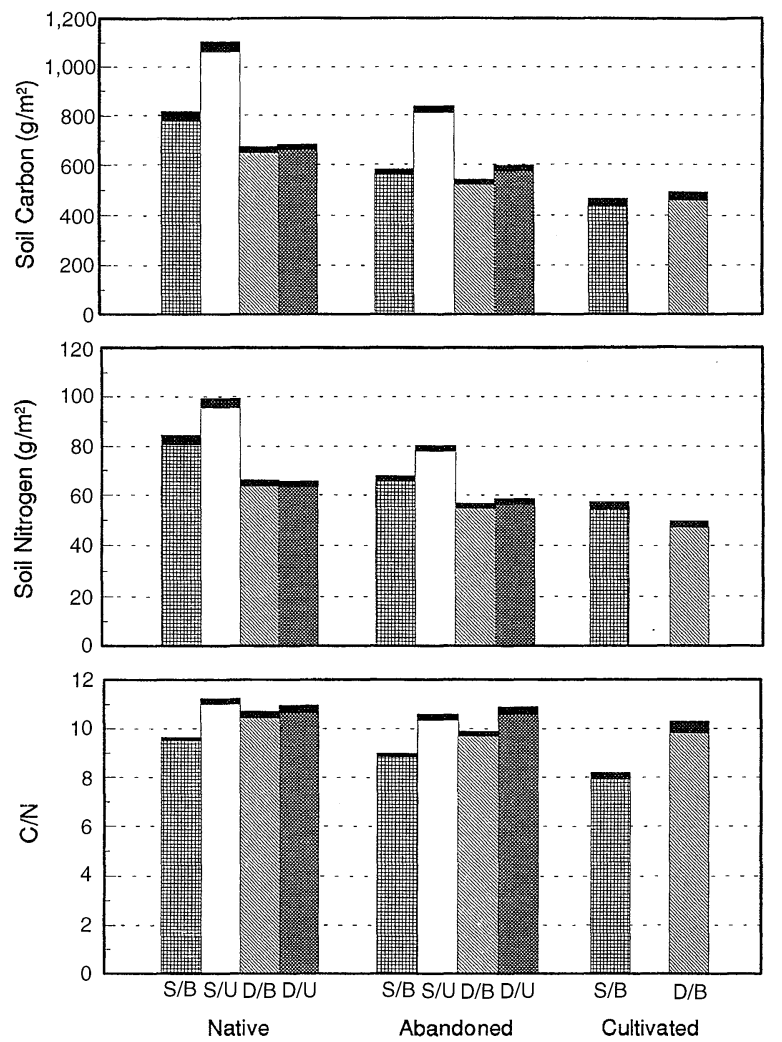

FIG. 1. Carbon, nitrogen, and carbon: nitrogen ratios from under and between individual Bouteloua gracilis plants in soils from 12 native and abandoned fields and 5 cultivated fields in northeastern Colorado. S/B, surface soils $(0-5 \mathrm{~cm})$, between plants; S/U, surface soils under plants; D/B, subsurface soils $(5-10 \mathrm{~cm})$, between plants; and D/U, subsurface soils under plants. Shaded sections on top of bars represent standard error of the mean.

were no differences between depths for either $\mathrm{C}$ or $\mathrm{N}$ in cultivated fields. Ratios of total $\mathrm{C} / \mathrm{N}$ had a pattern similar to that of $\mathrm{C}$ and $\mathrm{N}$, significantly narrower in cultivated than abandoned fields, and significantly wider under than between plants. The trends were the same as for unweighted data: $\mathrm{C}$ and $\mathrm{N}$ were highest in native fields, intermediate in abandoned, and lowest in cultivated fields (Table 1).

Soil texture was significantly affected by land-use treatment. Native fields had significantly higher silt contents and lower sand contents than either abandoned or cultivated fields (Fig. 2). Likewise, abandoned fields had significantly higher silt contents and lower sand contents than long-term cultivated fields. There were no significant effects of either depth or microsite on soil texture.

Microbial biomass $\mathrm{C}$ and $\mathrm{N}$ were significantly higher on both native and abandoned fields than on cultivated fields (Fig. 3). However, there were no significant differences between native and abandoned treatments with respect to microbial biomass for either microsite or depth. Both microbial $\mathrm{C}$ and $\mathrm{N}$ were higher under plants than between, and higher for surface soils than subsurface soils. The same trend existed for microbial C and $\mathrm{N}$ weighted by plant cover and summed for depths, with significantly lower microbial $\mathrm{C}$ and $\mathrm{N}$ in the cultivated than in the native and abandoned fields, but no difference between native and abandoned fields.

Potential net $\mathrm{C}$ and $\mathrm{N}$ mineralization were not significantly different among land-use treatments. Both $\mathrm{C}$ and $\mathrm{N}$ mineralization were significantly higher under plants than between, and higher in surface soils than at depth (Fig. 4). When the data were weighted to account for plant cover, there were significantly lower rates in soils incubated from cultivated fields, such that at a field level, there is less microbial activity and available $\mathrm{N}$ in the cultivated than in the native and abandoned fields (Table 1).

\section{DISCUSSION}

\section{Effect of long-term cultivation on soil pools and processes}

Our results support a large body of literature documenting significant reductions in soil organic matter as a result of long-term cultivation (Russel 1929, Hide and Metzger 1939, Haas et al. 1957, Tiessen et al. 1982, Burke et al. 1989, and many others). After at least 50

TABLE 1. $\mathrm{C}$ and $\mathrm{N}$ pools, microbial pools, and $\mathrm{C}$ and $\mathrm{N}$ mineralization rates in the surface $10 \mathrm{~cm}$ of soils from native grassland, fields that were abandoned in 1937, and fields that have been cultivated at least since 1937. The data are averaged across five sites for the $\mathrm{C}$ and $\mathrm{N}$ data and three sites for microbial biomass and mineralization, with each site having all three treatments. Values in parentheses represent standard errors of the means. All sites located in the Pawnee National Grasslands (PNG) of northeastern Colorado. Samples were collected from two depths $(0-5 \mathrm{~cm}$ and 5-10 $\mathrm{cm})$ and two microsites (between and under plants); data are summed by depth and weighted by total plant cover (under plant locations $\times$ plant cover + bare soil locations $\times$ cover of bare soil) for a single value that represents system-level pools and rates. Mineralization rates represent 10 -d laboratory incubations.

\begin{tabular}{|c|c|c|c|}
\hline & Native & Abandoned & Cultivated \\
\hline Total C $\left(\mathrm{g} / \mathrm{m}^{2}\right)$ & $1479 \quad(52)$ & (23) & (21) \\
\hline Total N $\left(\mathrm{g} / \mathrm{m}^{2}\right)$ & $86 \quad(11)$ & (6) & (5) \\
\hline $\mathrm{N}$ mineralized $\left(\mathrm{g} \cdot \mathrm{m}^{-2} \cdot \mathrm{d}^{-1}\right)$ & $0.12(0.02)$ & $0.12(0.01)$ & $0.10(0.01)$ \\
\hline $\mathrm{C}$ mineralized $\left(\mathrm{g} \cdot \mathrm{m}^{-2} \cdot \mathrm{d}^{-1}\right)$ & $2.33(0.35)$ & $2.54(0.41)$ & $1.86(0.28)$ \\
\hline Microbial C $\left(\mathrm{g} / \mathrm{m}^{2}\right)$ & $93.9 \quad(14.3)$ & $91.3 \quad(11.2)$ & $54.3(8.4)$ \\
\hline Microbial N $\left(\mathrm{g} / \mathrm{m}^{\mathrm{s}}\right)$ & 10.2 & $10.5(2.9)$ & $8.8(2.5)$ \\
\hline
\end{tabular}


yr of cultivation, surface soils $(0-10 \mathrm{~cm})$ at our study sites were $30-40 \%$ lower in $\mathrm{C}$ and $\mathrm{N}$ than adjacent native fields. These estimates are well within the range of other long-term studies (summarized in Schlesinger 1986), including our own work for these sites that studies soils to a $30-\mathrm{cm}$ depth (Ihori et al. 1995). We also found significant reductions in microbial biomass and microbial activity, as indexed by potential net $\mathrm{C}$ and $\mathrm{N}$ mineralization. Such reductions are probably due to long-term losses of organic matter resulting from high decomposition rates of recalcitrant fractions caused by tillage (Giddens 1957).

Our data also indicate, however, that soil erosion may be responsible for a portion of the total soil losses resulting from cultivation. The significant trend of highest sand content and lowest silt content on cultivated soils suggests that erosion may have preferentially removed fine material from cultivated fields. Fields that were cultivated for at least the last $50 \mathrm{yr}$ have apparently lost more fine material than the abandoned fields, which were cultivated for a shorter period of time. Changes in particle size distribution suggest
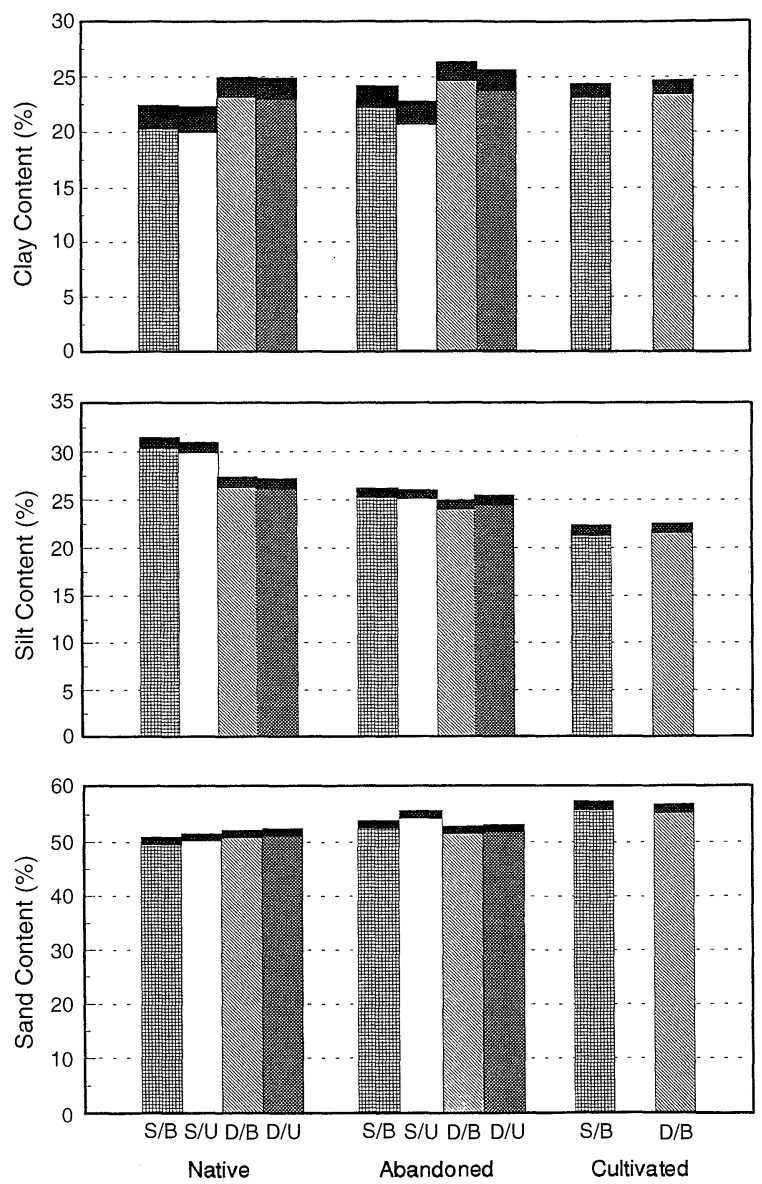

FIG. 2. Silt and sand content of soils from under and between individual Bouteloua gracilis plants from 12 native and abandoned fields and 5 cultivated fields in northeastern Colorado. Abbreviations and data presentation as in Fig. 1.
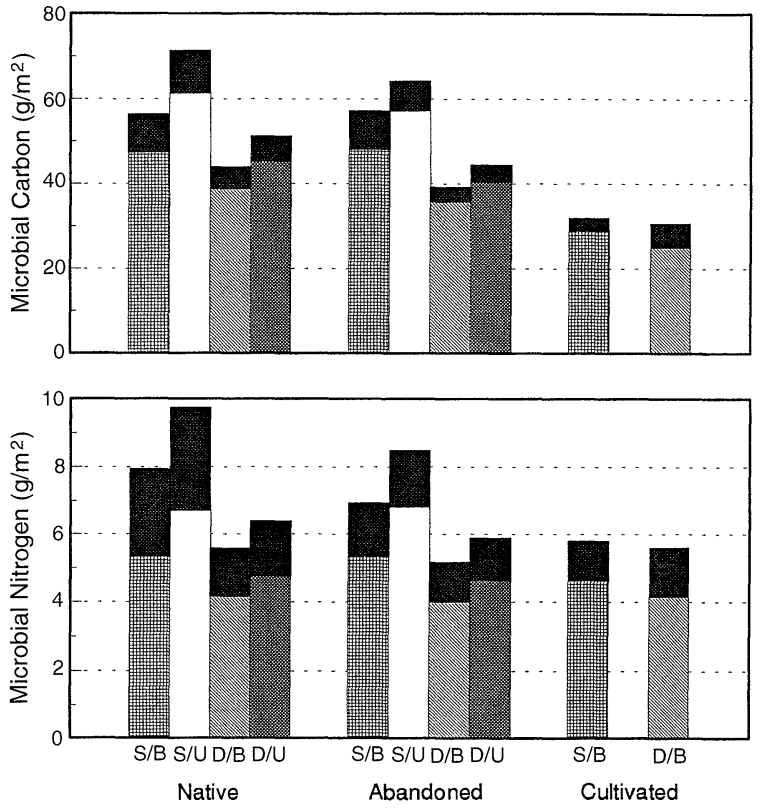

FIG. 3. Microbial biomass $\mathrm{C}$ and $\mathrm{N}$ from under and between individual Bouteloua gracilis plants in soils from 12 native and abandoned fields and 5 cultivated fields in northeastern Colorado. Abbreviations and data presentation as in Fig. 1.

that erosive losses of silt-sized particles have occurred as a result of cultivation. In our precipitation zone, wind is the most important historical vector for erosion (Muhs 1985), and the most logical current vector. A large body of work has demonstrated that silt-sized particles are more susceptible to wind erosion than either sand or clay (Gillette 1977, Gillette and Walker 1977, Zobeck and Fryear 1986). Clay is thought to be less erosive than silt due to its aggregative properties, and sand is less erosive due to the greater weight of these particles; thus, sand and clay patterns in percent composition may reflect silt movement. Such reductions in silt content could have a significant influence on recovery dynamics. Lauenroth et al. (1994) recently demonstrated that silt content significantly influences the rate of recovery of $B$. gracilis in shortgrass steppe, with a $10 \%$ reduction in silt content reducing seedling establishment rates by as much as $90 \%$.

\section{Recovery of systems from cultivation}

Assessment of recovery rates of abandoned fields is difficult, since no information was available on the status of these fields at the time of abandonment. Differences between abandoned and native fields are the result of both an unknown period and intensity of cultivation and an unknown rate of recovery. However, making an assumption about the effects of cultivation on small-scale heterogeneity can allow us to estimate rates of recovery. We assumed that cultivation, regardless of its intensity, homogenized the small-scale heterogeneity that was associated with individual pe- 

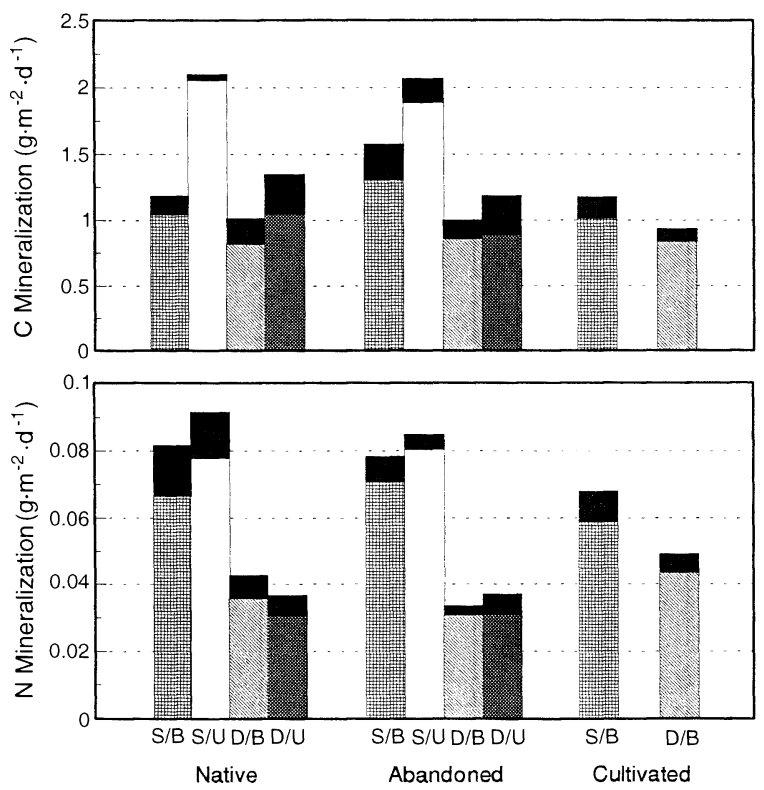

FIG. 4. Potentially mineralizable $\mathrm{C}$ and $\mathrm{N}$ from under and between individual Bouteloua gracilis plants in soils from 12 native and abandoned fields and 5 cultivated fields in northeastern Colorado. Abbreviations and data presentation as in Fig. 1.

rennial plants prior to initial tillage. Our results clearly show that small-scale heterogeneity in the abandoned fields has reestablished sometime during the $53 \mathrm{yr}$ since the fields were abandoned. Thus, the difference between plant and interspace soil organic matter pools can be used as a minimum estimate of the recovery of soil organic matter since abandonment.

Our results suggest that an average of $200 \mathrm{~g} / \mathrm{m}^{2}$ of $\mathrm{C}$ in the surface $5 \mathrm{~cm}$ has accumulated under individual B. gracilis plants in abandoned fields in a maximum period of $53 \mathrm{yr}$. This is very close to the magnitude of plant-interspace difference that occurs in native fields (Fig. 1). The additional soil $\mathrm{C}$ under plants is probably light fraction material (sensu Sollins et al. 1984) that has accumulated from above- and belowground litter. This amount of $\mathrm{C}$ represents $25-30 \%$ of the total C pool in the surface $5 \mathrm{~cm}$ of soil between plants. At the scale of the individual plant, soil $\mathrm{C}$ has recovered under plants in the abandoned fields to the point where it is equivalent to between-plant locations in the native fields. Such results suggest that the recovery dynamics of $B$. gracilis, the dominant species in the shortgrass steppe, may exert an important control over soil organic matter recovery in abandoned agricultural fields. Although the small-scale pattern suggests significant $\mathrm{C}$ recovery $\left(200 \mathrm{~g} / \mathrm{m}^{2}\right)$, when results were weighted by total plant cover, net increase in soil $\mathrm{C}$ is still relatively low $\left(82 \mathrm{~g} / \mathrm{m}^{2}\right)$.

We found that soil $\mathrm{N}$ was $15 \mathrm{~g} / \mathrm{m}^{2}$ higher under than between plants on abandoned fields. The accumulation of $\mathrm{N}$ under plants is probably due to redistribution of
$\mathrm{N}$ from areas surrounding plants to form plant biomass and then be deposited as litter. Thus, $\mathrm{C}$ accumulatior under plants represents net input into the ecosysten from the atmosphere as the result of photosynthesis but $\mathrm{N}$ accumulation under plants represents primaril: redistribution of $\mathrm{N}$. $\mathrm{N}$ in precipitation is most likely $\mathrm{t}$ be evenly distributed among plants and interspaces since interception is fairly small in these short plan canopies. Wider $\mathrm{C} / \mathrm{N}$ ratios under plants than betweer support this interpretation.

Studies of the short-term effects of management sug gest that there are lags in the response of nutrient avail ability to increases or decreases in total soil organic matter (Burke et al. 1995). During initial plow-out, $N$ availability may increase as decomposition increases until increased leaching and volatile losses reduce $N$ capital (Doran and Werner 1990) (Fig. 5). During recovery, active soil organic matter, as indexed by microbial biomass, may increase over a relatively short period of time (5-10 yr), in response to increased plant residue inputs and decreased tillage and decomposition (Doran 1980a, b. Rice and Smith 1984, Wood et al. 1990, Burke et al. 1995). In a number of studies, notillage systems have been found to result in a decreased nutrient availability relative to cultivated fields (Powlson 1980, Doran and Power 1983, House et al. 1984), suggesting an initial increased immobilization potential as a result of increases in C (Fig. 5), and again, a lag in the response of $\mathrm{N}$ availability to changes in total or active soil organic matter. In this study, we found that there was no significant difference between native and abandoned fields with respect to microbial biomass $\mathrm{C}$ and $\mathrm{N}$, or $\mathrm{C}$ and $\mathrm{N}$ mineralization, although total soil organic matter was still significantly lower in abandoned than in native fields. This suggests that active pools of soil organic matter (as indexed by microbial

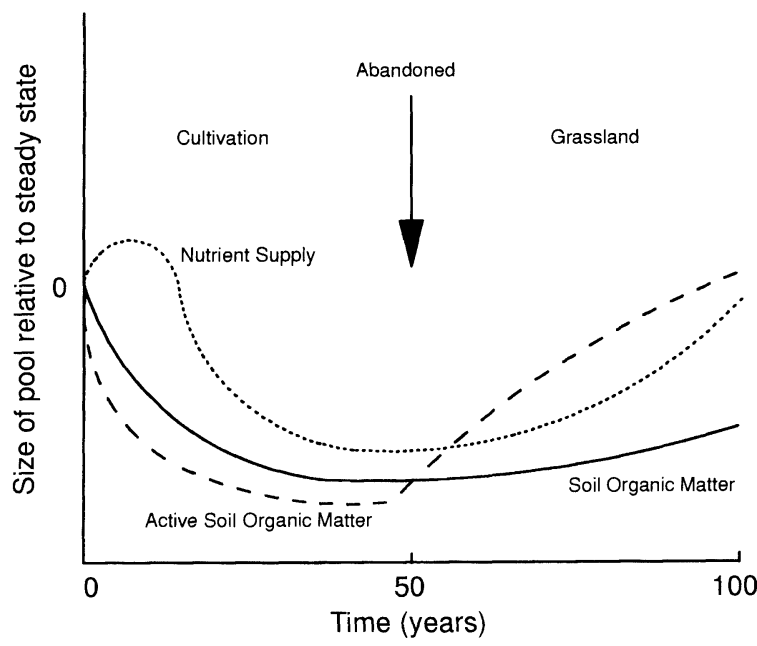

FIG. 5. Diagram of the responses of total soil organic matter, active soil organic matter, and nutrient supply to 50 $\mathrm{yr}$ of cultivation, and subsequently to $50 \mathrm{yr}$ of recovery as perennial grassland. 
biomass $\mathrm{C}$ and $\mathrm{N}$ ) and nutrient supply capacity (as indexed by potential $\mathrm{N}$ mineralization) have recovered in the abandoned fields during the past $50 \mathrm{yr}$ (Fig. 5). In addition, small-scale patterns in microbial biomass and mineralization were similar in abandoned and native fields, indicating that active soil organic matter and nutrient supply have recovered both at a small scale and at the field scale.

Models of soil organic matter dynamics generally represent pools responsible for nutrient supply- "active soil organic matter" (Parton et al. 1987, 1988)as having a turnover time of several years. Such models would predict rapid recovery of pools with short turnover times, as has been documented by studies that show increased microbial biomass after several years of improved management following cultivation. However, net mineralization from these pools is constrained by microbial immobilization, which is controlled by the amount and quality of plant residue added to the system. Initial increases in active soil organic matter do not correspond to increased nutrient availability to plants until immobilization potentials reach equilibrium. Our study suggests that this occurs in a period of $<50$ yr.

Long-term losses of soil organic matter from cultivated fields represent a significant decline in soil fertility, due to decreased nutrient availability. Losses of fine soil particles and total soil organic matter are not likely to be recovered over human time scales, since they represent pools that are accumulated over pedogenic periods (Schlesinger 1990). These slow fractions are lost with cultivation due to enhanced mixing and decomposition to rates far beyond those that occur in natural systems (Parton et al. 1983). However, it appears from this study that in shortgrass steppe, total soil organic matter can increase to some extent after several decades, and active soil organic matter and nutrient supply capacity can recover to initial levels (Fig. 5). In addition, small-scale heterogeneity characteristic of the shortgrass steppe can recover after $50 \mathrm{yr}$.

The view of ecosystem recovery resulting from this work emphasizes the interactions between plant population and ecosystem processes. The recovery of $\mathrm{C}$ and $\mathrm{N}$ pools is constrained by the rate of recovery of populations of perennial bunchgrasses such as $B$. gracilis (D. P. Coffin, W. K. Lauenroth, and I. C. Burke, unpublished manuscript). After $53 \mathrm{yr}$ of recovery, all the fields were dominated by perennial plants, but during initial stages, abandoned fields tend to be dominated by annuals (Judd and Jackson 1940). Vinton and Burke (1995) recently demonstrated that annual plants in shortgrass steppe do not accumulate significant levels of nutrients in soils beneath their canopies. While indications of recovery associated with individual plants suggest the potential for rapid recovery of $\mathrm{C}$ and $\mathrm{N}$ pools, the actual recovery of the field as a whole must await the reestablishment of precultivation density and number of individual perennial grasses. In par- ticular, the recovery and stability of fields may depend upon the establishment of Bouteloua gracilis. B. gracilis is the single most grazing- and drought-resistant species of the shortgrass steppe (Lauenroth and Milchunas 1992), and its presence is important to both the accumulation and the persistence of soil organic matter.

This framework may be important for land managers who are considering taking land out of production or enrolling in the Conservation Reserve Program. If the goal is to increase soil stability and fertility, and return land to a condition that may support forage production, reestablishment of perennial grasses will eventually lead to systems that have high $\mathrm{N}$ availability and soil stability. Alternatively, managers may not be able to justify regional shifts from cultivation in order to capture significant levels of terrestrial carbon. Our data suggest that carbon capture rates from recovering fields in semiarid regions are extremely slow.

\section{ACKNOWLEDGMENTS}

This research was supported by the National Science Foundation Shortgrass Steppe Long-Term Ecological Research Project (BSR-9011659), the Colorado State University Experiment Station Project Long-Term Grassland Ecosystem Research, and the Earthwatch Foundation. We thank Tamiko Ihori, Mark Lindquist, and the following Earthwatch volunteers for assistance with the fieldwork: Al Beeson, Morit Chatlynne, Donna Coates, Judith Conrad, David Jenney, Candis Harbison, Helen Lane, Judy Rothenberg, Donna Smith, Hall Smith, Marty Snyderman, Josephine Vania, and Judy Weinberg. We also thank Grant Godbolt, District Ranger, and the United States Forest Service, Greeley, Colorado office, for providing background material and access to the Pawnee National Grasslands. We thank Scott Warner for performing the statistical analyses and preparing graphics, Gus Shaver for a careful review of the manuscript, and Caroline Yonker for expert advice on soil erosion.

\section{Literature Cited}

Aguilar, R., E. F. Kelly, and R. D. Heil. 1988. Effects of cultivation on soils in northern Great Plains rangelands. Soil Science Society of America Journal 52:1081-1085.

Bauer, A., and A. L. Black. 1994. Quantification of the effect of soil organic matter content on soil productivity. Soil Science Society of America Journal 58:185-193.

Box, G. E. P., W. G. Hunter, and J. S. Hunter. 1978. Statistics for experimenters. John Wiley and Sons, New York, New York, USA.

Burke, I. C., E. T. Elliott, and C. V. Cole. 1995. Influence of macroclimate, landscape position, and management on soil organic matter in agroecosystems. Ecological Applications 5:124-131.

Burke, I. C., T. G. F. Kittel, W. K. Lauenroth, P. Snook, and C. M. Yonker. 1991. Regional analysis of the central Great Plains: sensitivity to climate variability. BioScience $\mathbf{4 1}$ : 685-692.

Burke, I. C., C. M. Yonker, W. J. Parton, C. V. Cole, K. Flach, and D. S. Schimel. 1989. Texture, climate, and cultivation effects on soil organic matter content in U.S. grassland soils. Soil Science Society of America Journal 53:800-805.

Day, P. R. 1965. Soil texture. In C. L. Black, editor. Methods of soil analysis. Part 2. Agronomy 9:545-567.

Doran, J. W. 1980a. Microbial changes associated with residue management with reduced tillage. Soil Science Society of America Journal 44:518-524.

- $1980 \mathrm{~b}$. Soil microbial and biochemical changes as- 
sociated with reduced tillage. Soil Science Society of America Journal 44:765-771.

Doran, J. W., and J. F. Power. 1983. The effects of tillage on the nitrogen cycle in corn and wheat production. Pages 441-455 in R. Lowrance, L. Asmussen, and R. Leonard, editors. Nutrient cycling in agroecosystems. Special publication 23. University of Georgia Experiment Station, Athens, Georgia, USA.

Doran, J. W., and M. R. Werner. 1990. Management and soil biology. Pages 205-230 in C. A. Francis, C. B. Flora, and L. D. King, editors. Sustainable agriculture in temperate zones. John Wiley and Sons, New York, New York, USA.

Elliott, E. T. 1986. Aggregate structure and carbon, nitrogen, and phosphorus in native and cultivated soils. Soil Science Society of America Journal 50:627-632.

EPA (Environmental Protection Agency). 1979. Methods for chemical analysis of water and wastes. EPA-600/4-79-020. U.S. Government Printing Office, Washington, D.C., USA.

Giddens, J. 1957. Rage of loss of carbon from Georgia soils. Soil Science Society of America Proceedings 21:513-515.

Gillette, D. A. 1977. Fine particulate emissions due to wind erosion. Transactions of the American Society of Agricultural Engineers 20:890-897.

Gillette, D. A., and T. R. Walker. 1977. Characteristics of airborne particles produced by wind erosion of sandy soil, high plains of Texas. Soil Science 123:97-110.

Great Plains Flora Association. 1986. Flora of the Great Plains. University Press of Kansas, Lawrence, Kansas, USA.

Haas, H. J., C. E. Evans, and E. R. Miles. 1957. Nitrogen and carbon changes in soils as influenced by cropping and soil treatments. USDA Technical Bulletin 1164. U.S. Government Printing Office, Washington, D.C., USA.

Hide, J. C., and W. H. Metzger. 1939. The effect of cultivation and erosion on the nitrogen and carbon of some Kansas soils. Agronomy Journal 31:625-632.

Hook, P. B., I. C. Burke, and W. K. Lauenroth. 1991. Heterogeneity of soil and plant $\mathrm{N}$ and $\mathrm{C}$ associated with individual plants and openings in North American shortgrass steppe. Plant and Soil 138:247-256.

House, G. F., B. R. Stinner, D. A. Crossley, Jr., E. P. Odum, and G. W. Langdale. 1984. Nitrogen cycling in conventional and no-tillage agroecosystems. Journal of Soil and Water Conservation 39:194-200.

Ihori, T., I. C. Burke, W. K. Lauenroth, and D. P. Coffin 1995. Effects of cultivation and abandonment on soil organic matter in northeastern Colorado. Soil Science Society of America Journal, in press.

Jenkinson, D. S., and D. S. Powlson. 1976. The effects of biocidal treatments on metabolism in soil. V. A method for measuring soil biomass. Soil Biology and Biochemistry 8 : 209-213.

Judd, I. B., and M. L. Jackson. 1940. Natural succession of vegetation on abandoned farmland in the Rosebud soil area of western Nebraska. American Society of Agronomy Journal 39:541-547.

Lauenroth, W. K., D. P. Coffin, and I. C. Burke. In press. Effects of plant mortality on population dynamics and ecosystem structure: a case study. In T. M. Smith, H. H. Shugart, and F. I. Woodward, editors. Plant functional types. Cambridge University Press, Cambridge, UK.

Lauenroth, W. K., and D. G. Milchunas. 1992. Short-grass steppe. Pages 183-226 in R. T. Coupland, editor. Ecosystems of the world 8A. Natural grasslands: introduction and Western Hemisphere. Elsevier, New York, New York, USA.

Lauenroth, W. K., O. E. Sala, D. P. Coffin, and T. B. Kirchner. 1994. Recruitment of Bouteloua gracilis in the shortgrass steppe: a simulation analysis of the role of soil water. Ecological Applications 4:741-749.

Muhs, D. R. 1985. Age and paleoclimatic significance of
Holocene sand dunes in northeastern Colorado. Annals of the Association of American Geographers 75:566-582.

Parton, W. J., D. W. Anderson, C. V. Cole, and J. W. B. Stewart. 1983. Simulation of soil organic matter formations and mineralization in semiarid agroecosystems. Pages 533-550 in R. R. Lowrance, R. L. Todd, L. E. Asmussen, and R. A. Leonard, editors. Nutrient cycling in agroecosystems. The University of Georgia, College of Agriculture Experiment Station, Special Publication Number 23.

Parton, W. J., D. S. Schimel, C. V. Cole, and D. S. Ojima. 1987. Analysis of factors controlling soil organic matter levels in Great Plains grasslands. Soil Science Society of America Journal 51:1173-1179.

Parton, W. J., J. W. B. Stewart, and C. V. Cole. 1988. Dynamics of $\mathrm{C}, \mathrm{N}, \mathrm{P}$, and $\mathrm{S}$ in grassland soils: a model. Biogeochemistry 5:109-131.

Powlson, D. S. 1980. Effect of cultivation on the mineralization of nitrogen in soil. Plant and Soil 57:151-153.

Rice, C. W., and M. S. Smith. 1984. Short-term immobilization of fertilizer nitrogen at the surface of no-till and plowed soils. Soil Science Society of America Journal 48: 295-297.

Russel, J. C. 1929. Organic matter problems under dry-farming conditions. Agronomy Journal 21:960-969.

SAS Institute. 1988. SAS/STAT user's guide, release 6.03 edition. SAS Institute, Cary, North Carolina, USA.

Schimel, D. S. 1986. Carbon and nitrogen turnover in adjacent grassland and cropland ecosystems. Biogeochemistry 2:345-357.

Schlesinger, W. H. 1986. Changes in soil carbon storage and associated properties with disturbance and recovery. Pages 194-220 in J. R. Trabalka, D. E. Reichle, editors. The changing carbon cycle: a global analysis. Springer-Verlag, New York, New York, USA.

- 1990. Evidence from chronosequence studies for a low carbon storage potential of soil. Nature 348:232-234.

Skold, M. D. 1989. Cropland retirement policies and their effects on land use in the Great Plains. Journal of Production Agriculture 2:197-201.

Snyder, J. D., and J. A. Trofymow. 1984. A rapid accurate wet oxidation diffusion procedure for determining organic and inorganic carbon in plant and soil samples. Communications in Soil Science and Plant Analysis 15:587-597.

Sollins, P., G. Spycher, and C. A. Glassman. 1984. Net nitrogen mineralization from light- and heavy-fraction forest soil organic matter. Soil Biology and Biochemistry 16:3137.

Tiessen, H., J. W. B. Stewart, and J. R. Bettany. 1982. Cultivation effects on the amounts and concentrations of carbon, nitrogen, and phosphorus in grassland soils. Agronomy Journal 74:831-835.

Tivy, J. 1987. Nutrient cycling in agroecosystems. Applied Geography 7:93-113.

U.S. Department of Agriculture. 1982. Soil survey of Weld County, Colorado: northern part. United States Department of Agriculture, Soil Conservation Service and Forest Service, in cooperation with Colorado Agricultural Experiment Station. U.S. Government Printing Office.

Vinton, M. A., and I. C. Burke. 1995. Interactions between individual plant species and soil nutrient status in shortgrass steppe. Ecology, in press.

Voroney, R. P., and E. A. Paul. 1984. Determination of Kc and $\mathrm{Kn}$ in situ for calibration of the chloroform fumigationincubation method. Soil Biology and Biochemistry 16:914.

Wood, C. M., D. G. Westfall, G. A. Peterson, and I. C. Burke. 1990. Impacts of cropping intensity on carbon and nitrogen mineralization under no-till dryland agroecosystems. Agronomy Journal 82:1115-1120. 
Yonker, C. M., D. S. Schimel, E. Paroussis, and R. D. Heil 1988. Patterns of organic carbon accumulation in a semiarid shortgrass steppe, Colorado. Soil Science Society of America Journal 52:478-483.
Zobeck, T. M., and D. W. Fryrear. 1986. Chemical and physical characteristics of windblown sediment. I. Quantities and physical characteristics. Transactions of the American Society of Agricultural Engineers 29:1032-1036. 